\title{
Anti-Termites Properties of Liquid Smoke from Bintangur Wood
}

\author{
Hasan Ashari Oramahi ${ }^{1}$, Farah Diba ${ }^{1,}$, Juanita $^{2}$ \\ ${ }^{1}$ Program Study of Forestry, Faculty of Forestry, Tanjungpura University. Jalan Daya Nasional, Pontianak, 78124, Kalimantan \\ Barat, Indonesia \\ 2 Master Program of Forest Science, Faculty of Forestry, Tanjungpura University. Jalan Daya Nasional, Pontianak, 78124, \\ Kalimantan Barat, Indonesia \\ * Corresponding author.E-mail address: farahdiba@fahutan.untan.ac.id
}

\section{ARTICLE HISTORY:}

Received: 26 January 2021

Peer review completed: 21 February 2021

Received in revised form: 25 April 2021

Accepted: 6 May 2021

\section{KEYWORDS:}

Acid content

Antitermitic activity

Bintangur wood

Phenol content

Wood vinegar

(C) 2021 The Author(s). Published by Department of Forestry, Faculty of Agriculture, University of Lampung in collaboration with Indonesia Network for Agroforestry Education (INAFE)

This is an open access article under the CC BY-NC license:

https://creativecommons.org/licenses/by$\mathrm{nc} / 4.0 \%$.

\begin{abstract}
Wood and wood-based products are very vulnerable to termite attacks. One of the methods to control termite attacks is using chemical insecticide. However, the use of chemical insecticide is considered a negative effect on the environment. The aim of this research was to determine the anti-termite properties of liquid smoke against Coptotermes curvignathus Holmgren. The liquid smoke derived from bintangur wood pyrolysis at $370^{\circ} \mathrm{C}, 400^{\circ} \mathrm{C}$, and $430^{\circ} \mathrm{C}$ was assessed as an anti-termite activity. Anti-termite activities against $C$. curvignathus were conducted by using liquid smoke with the concentration of $2 \%, 4 \%, 6 \%$, and $8 \%(\mathrm{v} / \mathrm{v})$. Simple linear regression was used to measure the effect of liquid smoke concentration against C. curvignathus. The results showed that the liquid smoke concentration of $6 \%$ and $8 \%$ at the three pyrolysis temperatures effectively controlled the subterranean termite's attack and resulted in $100 \%$ termites mortality. The chemical content of bintangur wood vinegar has contained phenol (1.23$1.65 \%)$ and acid (4.33-6.68\%).
\end{abstract}

\section{Introduction}

Termites are destructive organisms that cause damage to both plantation crops and forest plants (Calderon and Constantino 2007; Jasmi and Ahmad 2011). Termites are also known as organisms that can cause damage to buildings and household furniture from wood (Ghaly and Edwards 2011). Jasmi and Ahmad (2011) stated that the Coptotermes curvignathus is the main species of termite attacking Araucaria plants with a damage rate of $74 \%$ compared to Schedorhinotermes medioobscurus and Odontotermes sarawakensis termites.

Termite control using chemicals has been conducted for a long time, but these chemicals can cause harm to the environment and human health. In addition, the death of non-target organisms is the result of synthetic chemical use. Termite control using natural ingredients is an alternative effort to reduce losses due to synthetic chemicals. One of the alternative materials that can be used for termite control is liquid smoke.

Liquid smoke is a product of burning wood or biomass using a pyrolysis device at high temperatures without air (Lee et al. 2011). As a raw material for liquid smoke production, wood is generally composed of main components, such as cellulose, hemicellulose, and lignin (Liu et al. 2017). Liquid smoke contains complex chemical components so that it can function as anti- 
fungal (Gao et al. 2020) and anti-termite (Adfa et al. 2017). For example, liquid smoke obtained from wheat straw contains chemical components including m-cresol, 3,4-dihydroxy toluene, ocresol, acetic acid, 4-ethyl phenol, 3-methyl catechol, propionic acid 2-ethyl phenol, and 4- ethyl phenol. This liquid smoke can inhibit the growth of the fungus Fusarium graminearum (Gao et al. 2020).

Adfa et al. (2017) stated that liquid smoke from surian wood (Toona sinensis A. Juss) contains dominant chemical components such as acetic acid. The results showed that the liquid smoke functioned as an anti-termite agent (Adfa et al. 2017). Another study conducted by Oramahi et al. (2018) stated that liquid smoke from palm oil stems has anti-termite activity. The anti-termite activity of liquid smoke is strongly influenced by the chemical components of liquid smoke, such as acids, phenols, and phenol derivatives. These chemical components are influenced by the pyrolysis temperature and the biomass source used.

This study aims to evaluate the efficacy of liquid smoke from bintangur wood (Calophyllum inophyllum Linnaeus) at pyrolysis temperatures of $370^{\circ} \mathrm{C}, 400^{\circ} \mathrm{C}$, and $430^{\circ} \mathrm{C}$ against subterranean termites $C$. curvignathus. In addition, analysis of the constituent components of liquid smoke as phenol and acid contents at the three temperatures was also carried out.

\section{Materials and Methods}

\subsection{Materials Preparation and Liquid Smoke Production}

The preparation of bintangur wood (Calophyllum inophyllum Linnaeus) was carried out at the Wood Workshop Laboratory, Faculty of Forestry, Tanjungpura University, Pontianak. Bintangur wood raw material was obtained from sawmills in Pontianak. Bintangur wood was crushed into powder with a size of a 40 mesh sieve and retained by 60 mesh. The manufacture of liquid smoke was carried out by pyrolysis at the Engineering Laboratory of the Faculty of Agricultural Technology, Gadjah Mada University, Yogyakarta. Testing the efficacy of bintangur wood liquid smoke against subterranean termites Coptotermes curvignathus Holmgren was carried out at the Wood Technology Laboratory, Faculty of Forestry, Tanjungpura University. The production of liquid smoke applied the pyrolysis method following the previous studies (Darmadji and Triyudiana 2006; Oramahi et al. 2020a). The liquid smoke was manufactured through the following steps: bintangur wood powder was put into an aluminum reactor with a maximum capacity of $5 \mathrm{~kg}$ particle, then closed. A series of aluminum condensers was then installed, the heating furnace was turned on at a temperature of $370^{\circ} \mathrm{C}, 400^{\circ} \mathrm{C}$, and $430^{\circ} \mathrm{C}$ with pyrolysis time for 120 minutes. The pyrolysis process is presented in Fig. 1.

\subsection{Total Phenol Analysis}

The total phenol analysis procedure was carried out based on Senter et al. (1989) as follows: (1) $1 \mathrm{ml}$ of liquid smoke from bintangur wood was weighed and diluted with distilled water to reach a volume of $1,000 \mathrm{ml}$, (2) $1 \mathrm{ml}$ of the solution is taken and then added as much as $5 \mathrm{ml}$ of alkaline $\mathrm{NaCO}_{3}$ (1 molar) solution, (3) The solution is left at $27^{\circ} \mathrm{C}$ for 10 minutes, (4) then added as much as $0.5 \mathrm{ml}$ of Folin-ciocalteu reagent (commercial reagent: distilled water $(1: 1) \mathrm{v} / \mathrm{v}$ ) and shaken using a vortex-shaker, (5) then left for 30 minutes, and the absorbance was read with a spectrophotometer (UV-Vis Shimadzu 1601, Japan) on a blank solution using a wavelength of 750 
$\mathrm{nm}$, and (6) the phenolic concentration of the sample solution was calculated based on the standard curve obtained from the pure phenol solution.

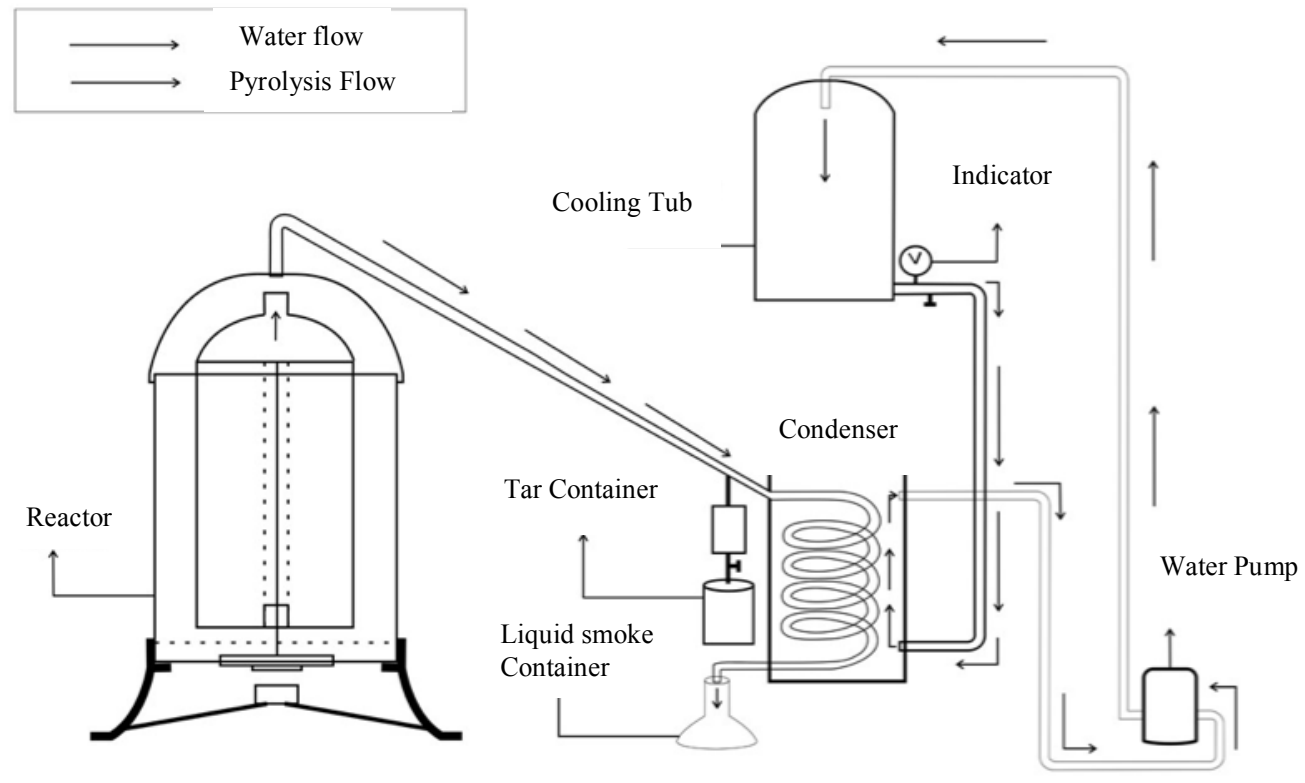

Fig. 1. Schematic of a tool for liquid smoke production through pyrolysis.

\subsection{Total Acid Analysis}

The total acid analysis procedure was carried out based on AOAC (1990) as follows: (1) liquid smoke from bintangur wood was weighed about $1 \mathrm{~mL},(2)$ then diluted with distilled water to reach a volume of $100 \mathrm{~mL}$, (3) titrated with $0.1 \mathrm{~N} \mathrm{NaOH}$ standard solution to $\mathrm{pH}$ reaches 8 , and (4) the acid content is expressed in percent by weight of acetic acid.

\subsection{Coptotermes curvignathus Termites Collection}

Subterranean termites were obtained from infected tree stands in the area of the Ambawang River, Kubu Raya Regency, West Kalimantan, Indonesia. The termite used was C. curvignathus (worker and soldier castes). The characteristics of worker and soldier termites refer to procedures (Nandika et al. 2003). Maintenance of C. curvignathus was carried out in the laboratory with the following procedures (1) put the termites in a bucket that has been given rubberwood as a food source, (2) the bucket containing termites was covered with black plastic so that moisture is maintained, (3) this maintenance was carried out for 3 weeks before the study.

\subsection{Testing of Liquid Smoke against Coptotermes curvignathus Termites In Vitro}

Testing the efficacy of bintangur wood liquid smoke against $C$. curvignathus was carried out at the Wood Technology Laboratory, Faculty of Forestry, Tanjungpura University. The testing was referred to Kang et al. (1990) and Ganapaty et al. (2004). About $0.3 \mathrm{ml}$ of liquid smoke from bintangur wood was dropped on filter paper media (Whatman number 1, diameter $55 \mathrm{~mm}$ ). The filter paper was placed on a plastic cup with a diameter of $60 \mathrm{~mm}$. The subterranean termites $C$. curvignathus (soldiers and workers) with a composition of 50 workers and 5 soldiers were placed on plastic plates and stored in the termite incubation room at a temperature of $27^{\circ} \mathrm{C}$ with a humidity of $70-80 \%$. 
Incubation was carried out for 21 days and observations were made every day to evaluate termite mortality. The filter paper as control was dripped with distilled water as much as $0.3 \mathrm{ml}$. The study used variations in the concentration of liquid smoke, such as $0 \%, 2 \%, 4 \%, 6 \%$, and $8 \%$, with four replications.

Percentage of termite mortality and filter paper weight loss as observation variables refers to Owoyemi et al. (2011) as follows:

$$
\text { Mortality }(\%)=\frac{N_{1}-N_{2}}{N_{1}} \times 100 \%
$$

where $N_{l}$ is the number of initial termites, and $N_{2}$ is the number of termites at the end of the test.

$$
\text { Filter paper weight loss in }(\%)=\frac{B_{1}-B_{2}}{B_{1}} \times 100 \%
$$

where $B_{1}$ is the weight of the initial filter paper $(\mathrm{g})$, and $B 2$ is the weight of the filter paper at the end of the test $(\mathrm{g})$.

\subsection{Experiment Design and Data Analysis}

The experimental design was used to evaluate the effect of pyrolysis temperature in liquid smoke production of bintangur wood on the mortality of $C$. curvignathus and weight loss of filter paper using a factorial completely randomized design. The first factor was the pyrolysis temperature during the liquid smoke production from bintangur wood, consisting of $370^{\circ} \mathrm{C}, 400^{\circ} \mathrm{C}$, and $430^{\circ} \mathrm{C}$. The second factor was the concentration of liquid smoke from bintangur wood consisting of $0 \%, 2 \%, 4 \%, 6 \%$, and $8 \%$. Data on the mortality of C. curvignathus and weight loss of filter paper were analyzed using variance (ANOVA). An honestly significant difference test was carried out at $5 \%$ significance level to determine differences between treatments.

The use of simple linear regression analysis was to determine the effect of liquid smoke concentration of bintangur wood $(x)$ on the mortality of $C$. curvignathus, and weight loss of filter paper $(Y)$. The simple regression equation refers to Montgomery (1991):

$$
Y=b o+b x
$$

where $b o$ is constant and $b$ is regression coefficient.

Analysis of variance was conducted using SAS, and the simple linear regression analysis was conducted using the Statistical Package for Social Science (SPSS) program version 22 (SPSS Inc., USA).

\section{Results and Discussion}

\subsection{Chemical Components of Liquid Smoke from Bintangur Wood}

The constituent components of liquid smoke as total phenol and total acid, are shown in Table 1. The total phenol component in the liquid smoke of bintangur wood was $1.23-1.42 \%$, while the acid content was 4.33-6.68\%. Adfa et al. (2020) stated that liquid smoke from Cinnamomum parthenoxylon contains chemical components such as acids and phenols as the dominant compounds. The acid compounds were acetic acid of $42.91 \%$ and phenolic compounds, such as 2-dimethoxy phenol of 5.51\%. Meanwhile, the acid and phenol content in liquid smoke was obtained from a mixture of Acacia mangium Willd and Vitex pubescens Vahl wood sawdust were 6.05-8.73\% and 2.13-6.70\%, respectively (Oramahi et al. 2011). Alias et al. (2020) obtained the content of phenol, mequinol, 4-methyl phenol, 4-ethyl phenol, and acetic acid in bamboo liquid 
smoke were $11.57 \%, 14.87 \%, 2.85 \%, 11.46 \%$, and $8.45 \%$, respectively. The difference in phenol and acid content in this study was caused by differences in the raw materials for the liquid smoke production.

Table 1. The constituent components of liquid smoke from bintangur wood at various pyrolysis temperatures

\begin{tabular}{ccc}
\hline Pyrolysis Temperature & \multicolumn{3}{c}{ Components } \\
\cline { 2 - 3 }$\left({ }^{\circ} \mathbf{C}\right)$ & Phenol (\%) & Acid (\%) \\
\hline 370 & 1.42 & 4.33 \\
400 & 1.23 & 6.13 \\
430 & 1.65 & 6.68 \\
\hline
\end{tabular}

Notes: The means are averages of 3 replicates.

Table 1 shows that the increase in acid and phenol is influenced by pyrolysis temperature. The higher pyrolysis temperature indicated the increase of acid and phenol levels. However, the phenol content tends to decrease at $400^{\circ} \mathrm{C}$. Wu et al. (2015) reported that the phenol content of liquid smoke at $450^{\circ} \mathrm{C}$ was higher than the phenol content at $350^{\circ} \mathrm{C}$. The results of this study showed a tendency to increase the constituent content of liquid smoke with an increase in the pyrolysis temperature of liquid smoke production. The phenol content in liquid smoke from bamboo is formed from the pyrolysis of lignin, while acetic acid is formed from the pyrolysis of cellulose and hemicellulose (Theapparat et al. 2015).

\subsection{Mortality of Coptotermes curvignathus Termites}

The mortality percentage of $C$. curvignathus and weight loss of filter paper at different pyrolysis temperatures and concentrations of liquid smoke is presented in Table 2. The analysis showed that the treatment of liquid smoke concentration from bintangur wood and pyrolysis temperature of liquid smoke production $\left(370^{\circ} \mathrm{C}, 400^{\circ} \mathrm{C}\right.$, and $\left.430^{\circ} \mathrm{C}\right)$ had a significant effect on termite mortality and weight loss. The effect of liquid smoke on termite mortality at a liquid smoke concentration of $4 \%$ resulted in the highest mortality $(90.91 \%)$ at a pyrolysis temperature of $430^{\circ} \mathrm{C}$ compared to that of termites at temperatures of $370^{\circ} \mathrm{C}$ and $400^{\circ} \mathrm{C}$ (Table 2). The difference in the ability of liquid acid anti-crawl activity is influenced by several factors, including the concentration of liquid smoke and the chemical components of liquid smoke (Adfa et al. 2017; Oramahi et al. 2020b). These results were in line with Oramahi et al. (2020b), stating that the liquid smoke from bengkirai wood and oil palm empty fruit bunches (OPEFB) has differences in its antitermite properties. OPEFB liquid smoke has the highest anti-termite activity against Coptotermes formosanus termites at a temperature of $450^{\circ} \mathrm{C}$ compared to $350^{\circ} \mathrm{C}$, with a concentration of $10 \%$. Subekti and Yoshimura (2020) reported that liquid smoke from bamboo at a pyrolysis temperature of $450^{\circ} \mathrm{C}$ effectively controlled $C$. formosanus termites, with a mortality rate of $100 \%$ on day 14 with a concentration of $10 \%$. 
Table 2. Termite mortality and filter paper weight loss at different pyrolysis temperatures and liquid smoke concentrations

\begin{tabular}{cccc}
\hline \multicolumn{2}{c}{ Treatment } & & \\
\cline { 1 - 2 } $\begin{array}{c}\text { Pyrolysis } \\
\text { Temperature } \\
\left({ }^{\circ} \mathbf{C}\right)\end{array}$ & $\begin{array}{c}\text { Liquid Smoke } \\
\text { Concentration (\%) }\end{array}$ & Termite Mortality (\%) & $\begin{array}{c}\text { Filter Paper Weight Loss } \\
(\%)\end{array}$ \\
\hline $\begin{array}{c}\text { Control } \\
370\end{array}$ & 0 & $17.00(1.52)^{\mathrm{a}}$ & $41.21(1.73)^{\mathrm{i}}$ \\
& 2 & $64.40(2.90)^{\mathrm{b}}$ & $20.97(0.52)^{\mathrm{h}}$ \\
& 4 & $75.76(2.47)^{\mathrm{dd}}$ & $14.83(2.68)^{\mathrm{fg}}$ \\
400 & 6 & $100.00(0.00)^{\mathrm{f}}$ & $8.84(1.07)^{\mathrm{bcd}}$ \\
& 8 & $100.00(0.00)^{\mathrm{f}}$ & $6.86(1.29)^{\mathrm{bc}}$ \\
& 2 & $69.70(4.29)^{\mathrm{bc}}$ & $18.30(0.89)^{\mathrm{gh}}$ \\
430 & 6 & $81.84(2.47)^{\mathrm{d}}$ & $12.60(1.37)^{\mathrm{def}}$ \\
& 8 & $100.00(0.00)^{\mathrm{f}}$ & $8.71(1.17)^{\mathrm{bcd}}$ \\
& 2 & $100.00(0.00)^{\mathrm{f}}$ & $6.12(0.75)^{\mathrm{ab}}$ \\
& 4 & $81.06(3.81)^{\mathrm{d}}$ & $13.52(1.55)^{\mathrm{efg}}$ \\
& 6 & $90.91(2.47)^{\mathrm{e}}$ & $10.16(0.80)^{\mathrm{cde}}$ \\
8 & $100.00(0.00)^{\mathrm{f}}$ & $7.80(1.62)^{\mathrm{bcd}}$ \\
& $100.00(0.00)^{\mathrm{f}}$ & $5.06(2.11)^{\mathrm{abc}}$ \\
\hline
\end{tabular}

Notes: Numbers in parenthesis are standard deviations. Means within a column followed by the same letter are not significantly different at $5 \%$ significance level using the LSD test.

The mortality of $C$. curvignathus due to treatment of liquid smoke from bintangur wood at various pyrolysis temperatures and concentrations of liquid smoke for 21 days is shown in Fig. 24.

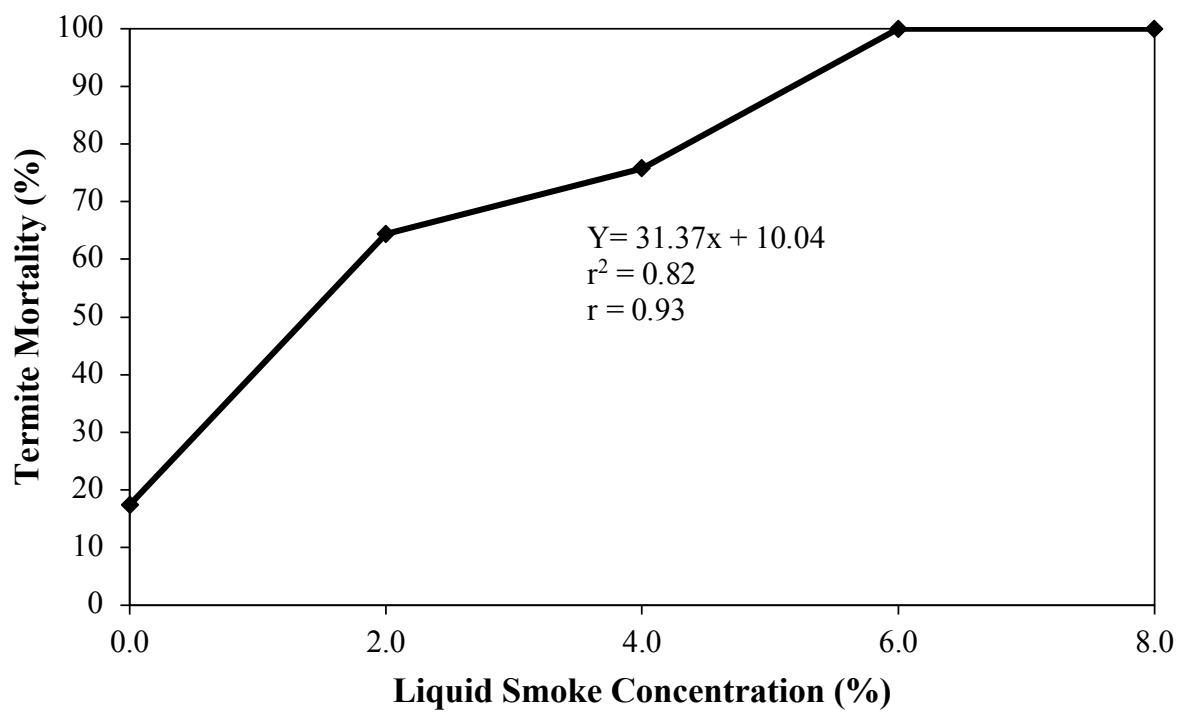

Fig. 2. Correlation between the concentration of bintangur wood liquid smoke at pyrolysis temperature of $370^{\circ} \mathrm{C}$ and mortality of Coptotermes curvignathus. 


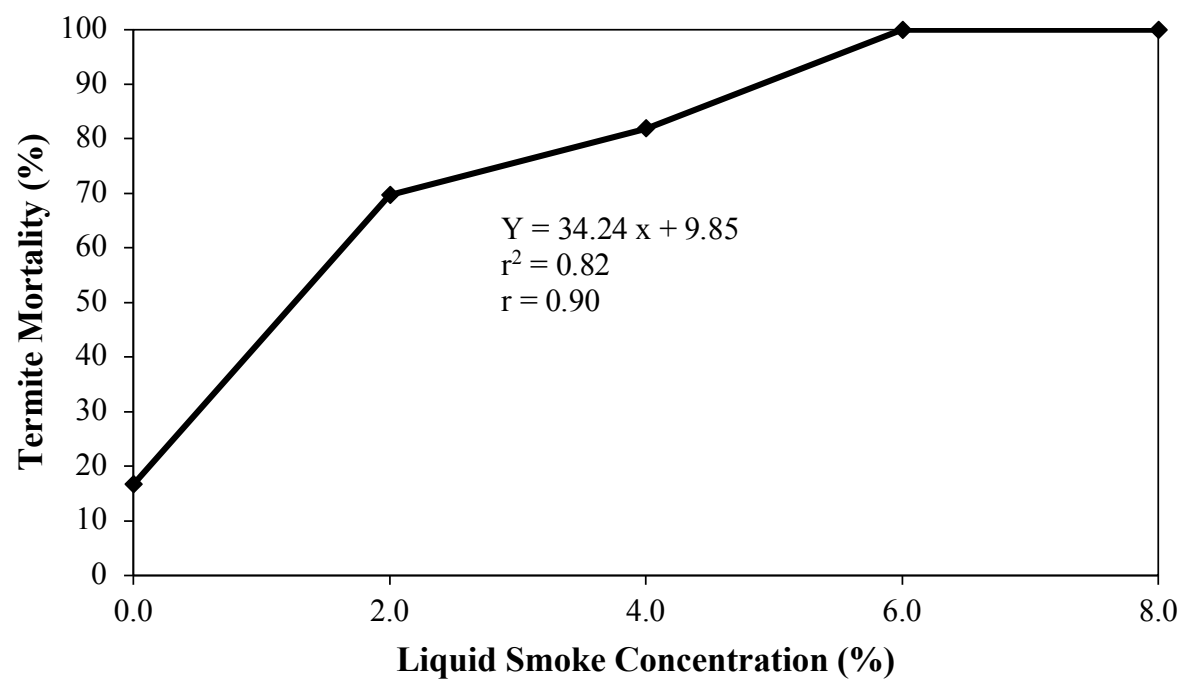

Fig. 3. Correlation between the concentration of bintangur wood liquid smoke at pyrolysis temperature of $400^{\circ} \mathrm{C}$ and mortality of Coptotermes curvignathus.

The correlation value between the concentration of bintangur wood liquid smoke and termite mortality at pyrolysis temperatures of $370^{\circ} \mathrm{C}, 400^{\circ} \mathrm{C}$, and $430^{\circ} \mathrm{C}$ were $0.93,0.90$, and 0.84 , respectively, indicating a positive and strong correlation $(\mathrm{p}<0.05)$. The simple regression equation and the coefficient determination in the treatment of bintangur wood liquid smoke concentration on the mortality of C. curvignathus at pyrolysis temperatures of $370^{\circ} \mathrm{C}, 400^{\circ} \mathrm{C}$, and $430^{\circ} \mathrm{C}$ are $\mathrm{Y}$ $=31.37 \mathrm{x}+10.04$ and $0.87, \mathrm{Y}=34.24 \mathrm{x}+9.85$ and 0.82 , and $\mathrm{Y}=40.15 \mathrm{x}+9.36$ and 0.70 , respectively. This equation shows that the higher the concentration of liquid smoke from bintangur wood is followed by the high mortality of $C$. curvignathus. This result shows that the higher concentration of liquid smoke indicated the higher levels of the components in the liquid smoke, which have anti-termite properties. The results of this study are in line with the results of research by Adfa et al. (2020), stating that increasing the concentration of liquid smoke from cinnamon (Cinnamomum parthenoxylon) significantly led to an increase in the mortality of C. curvignathus.

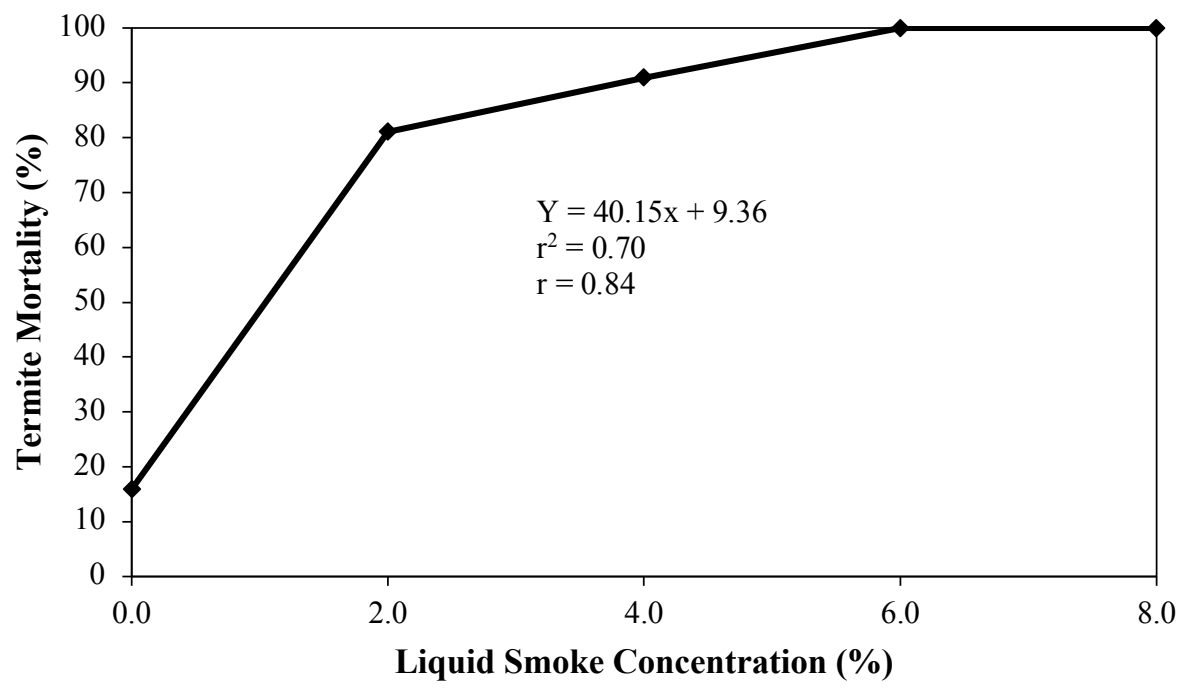

Fig. 4. Correlation between the concentration of bintangur wood liquid smoke at pyrolysis temperature of $430^{\circ} \mathrm{C}$ and Coptotermes curvignathus mortality. 
Shiny and Remadewi (2014) examined the ability of liquid smoke from coconut shells against the subterranean termites Odontotermes horni (Wasmann), O. obesus (Rambur), O. redamanni (Wasmann), and Microtermes obesi (Holmgren). The results showed that the higher the concentration of coconut shell liquid smoke caused an increase in termite mortality. This is because the active ingredients in liquid smoke, mainly phenols and phenol derivatives, are more at higher concentrations. Oramahi et al. (2018) stated that the mortality of Coptotermes formosanus subterranean termites significantly increased with an increase in the concentration of liquid smoke from oil palm stems. The two previous studies are in line with the results obtained, such as the highest termite mortality value was obtained at a concentration of $6 \%$ and $8 \%$ in the three pyrolysis temperatures.

\subsection{Filter Paper Weight Loss}

The effect of the liquid smoke of bintangur wood on the weight loss of filter paper by C. curvignathus at various pyrolysis temperatures and concentrations of bintangur wood liquid smoke is shown in Fig. 5-7. The simple regression equation and the coefficient determination on the treatment of bintangur wood liquid smoke concentration on the weight loss of filter paper at pyrolysis temperatures of $370^{\circ} \mathrm{C}, 400^{\circ} \mathrm{C}$, and $430^{\circ} \mathrm{C}$ are $\mathrm{Y}=34.71 \mathrm{x}-4.04$ and $0.84, \mathrm{Y}=33.34 \mathrm{x}-$ 3.99 and 0.80 , and $\mathrm{Y}=31.15 \mathrm{x}-3.90$ and 0.70 , respectively. This equation shows that the higher the concentration of liquid smoke from bintangur wood indicated the lower weight loss of filter paper due to $C$. curvignathus. This is related to the eating activity of termites in consuming filter paper as food. The correlation between the pyrolysis temperature during liquid smoke production and the decrease in filter paper weight due to termites was influenced by termite mortality. This is because the surviving termites still consume filter paper, resulting in a high reduction in weight. Fig. 5-7 explains that the treatment of bintangur wood liquid smoke concentration (2-8\%) against C. curvignathus resulted in a decrease in filter paper weight by $5.06-20.97 \%$. The results of this study support the results of the research of Oramahi and Yoshimura (2013), stating that the application of liquid smoke from laban wood (Vitex pubescens Vahl) at a liquid smoke concentration of $1-5 \%$ against Reticulitermes speratus termites causes a decrease in filter paper weight by $6.70-23.70 \%$.

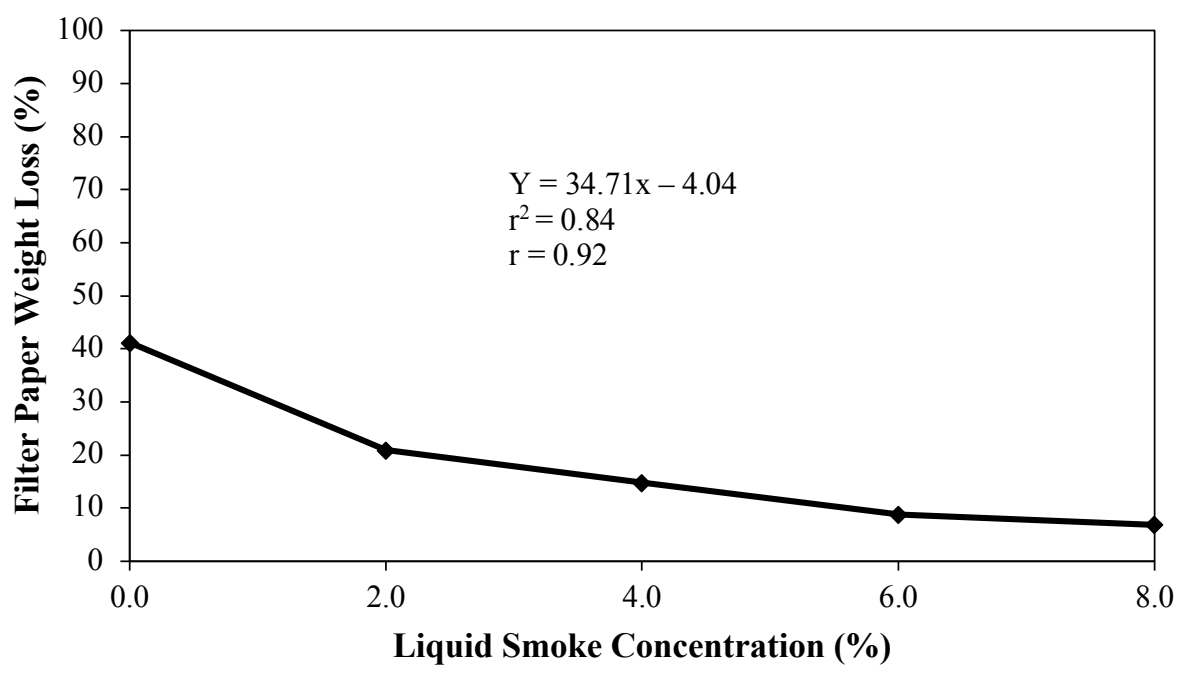

Fig. 5. Correlation between the concentration of bintangur wood liquid smoke at pyrolysis temperature of $370^{\circ} \mathrm{C}$ and the weight loss of filter paper. 


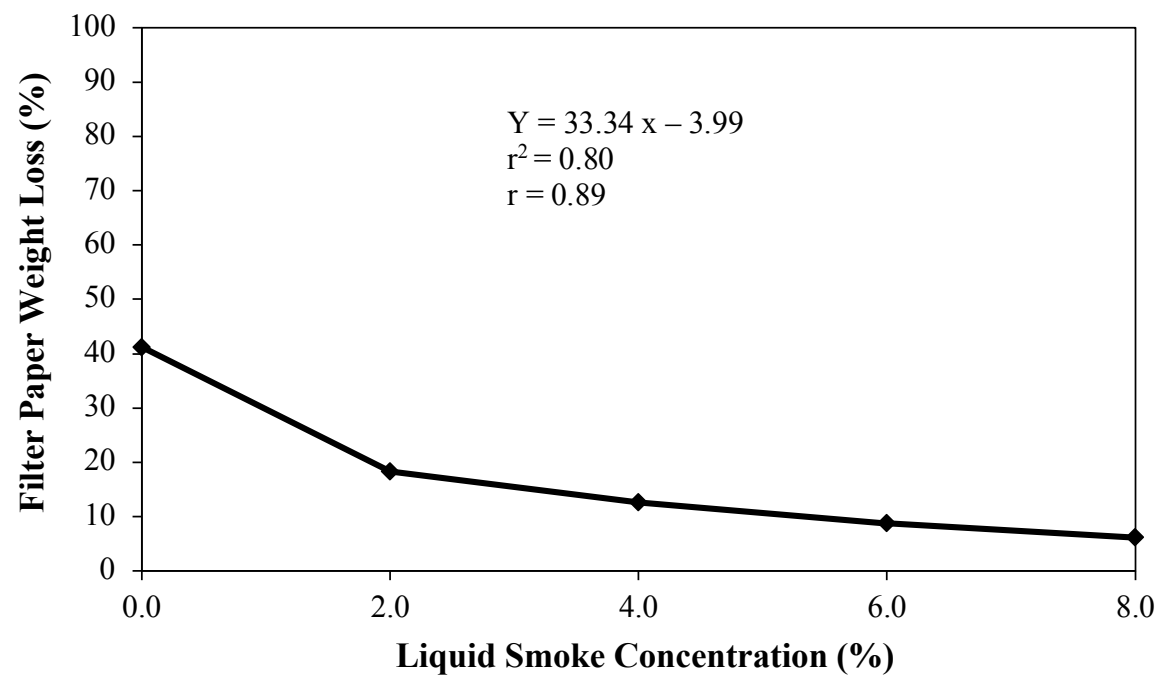

Fig. 6. Correlation between the concentration of bintangur wood liquid smoke at pyrolysis temperature of $400^{\circ} \mathrm{C}$ and the weight loss of filter paper.

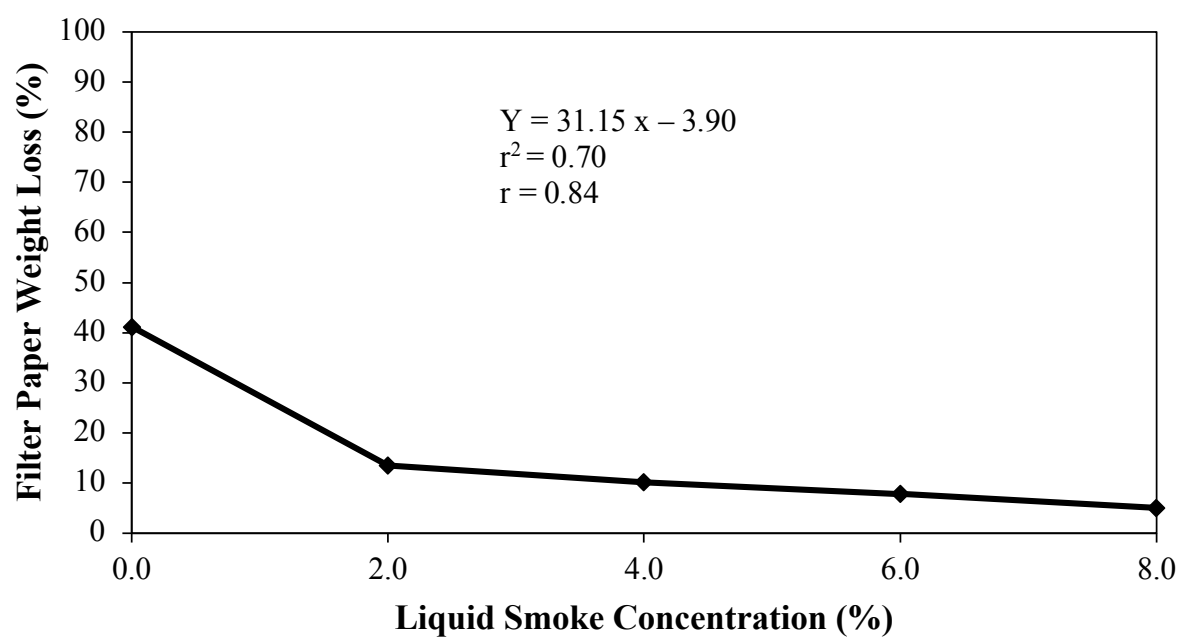

Fig. 7. Correlation between the concentration of bintangur wood liquid smoke at pyrolysis temperature of $430^{\circ} \mathrm{C}$ and the weight loss of filter paper.

\section{Conclusions}

Bintangur wood liquid smoke (Calophyllum inophylum Linnaeus) has the ability to act as an anti-termites agent against Coptotermes curvignathus Holmgren subterranean termites. Bintangur wood liquid smoke concentrations of $6 \%$ and $8 \%$ at three pyrolysis temperatures $\left(370^{\circ} \mathrm{C}, 400^{\circ} \mathrm{C}\right.$, and $430^{\circ} \mathrm{C}$ ) resulted in a subterranean termite mortality value of $100 \%$. The lower the percentage of weight loss value of filter paper indicated the higher concentration of liquid smoke. The chemical components in bintangur wood liquid smoke contained phenol (1.23-1.65\%) and acids (4.33-6.68\%). The optimal concentration of bintangur wood liquid smoke in inhibiting termite attack is $6 \%$ at pyrolysis temperatures of $370^{\circ} \mathrm{C}, 400^{\circ} \mathrm{C}$, and $430^{\circ} \mathrm{C}$. 


\section{Acknowledgments}

The author would like to thank the Ministry of Research and Technology/National Research and Innovation Agency for the 2020 budget with contract number SP DIPA-042.06.1.401516/2020 through a Master Thesis Research grant and involving two of the Master Student of Forestry Science Program, Faculty of Forestry, University Tanjungpura with the name of Juanita and Rizka Diah Permana. The author also would like to thank Alkhadi, who has helped in the implementation of this research.

\section{References}

Adfa, M., Kusnanda, A. J., Livandri, F., Rahmad, R., Darwis, W., Efdi, M., Ninomiya, and Koketsu, M. 2017. Insecticidal Activity of Toona sinensis against Coptotermes curvignathus Holmgren. Rasayan Journal of Chemistry 10(1): 153-159. DOI: 10.7324/rjc.2017.1011590

Adfa, M., Romayasa, A., Kusnanda, A. J., Avidlyandi, Yudha, S., Banon, C., and Gustian, I. 2020. Chemical Components, Antitermite and Antifungal Activities of Cinnamomum parthenoxylon Wood Vinegar. Journal of the Korean Wood Science and Technology. 48(1): 107-116. DOI: 10.5658/wood.2020.48.1.107

Alias, N. Z., Abdullah, S., Shaari, S. S., Junik, J. J., Kamal, M. L., and Masdar, N. D. 2020. The Potential of Bamboo Vinegar (Gigantochloa albociliata) as Insecticide. In Charting the Sustainable Future of ASEAN in Science and Technology. Springer. Singapore. DOI: 10.1007/978-981-15-3434-8_7

AOAC. 1990. Official Methods of Analysis. Association of Official Analytical Chemists (AOAC). Arlington.

Calderon, R. A., and Constantino, R. 2007. A Survey of the Termite Fauna (Isoptera) of an Eucalypt Plantation in Central Brazil. Neotropical Entomology 36(3): 391-395. DOI: 10.1590/s1519-566x2007000300007

Darmadji, P., and Triyudiana, H. 2006. Proses Pemurnian Asap Cair dan Simulasi Akumulasi Kadar Benzopyrene pada Proses Perendaman Ikan. Agritech 2: 94-103. DOI: 10.22146/agritech.9477

Ganapaty, S., Thomas, P. S., and Fotso, L. H. 2004. Antitermitic Quinones from Diospyros sylvatica. Phytochemistry 65(9): 1265-1271. DOI: 10.1016/j.phytochem.2004.03.011

Gao, T., Bian, R., Joseph, S., Taherymoosavi, S., Mitchell, D. R., Munroe, P., and Shi, J. 2020 Wheat Straw Vinegar: A More Cost-Effective Solution than Chemical Fungicides for Sustainable Wheat Plant Protection. Science of the Total Environment 10(725): 138359. DOI: $10.1016 /$ j.scitotenv.2020.138359

Ghaly, A., and Edwards, S. 2011. Termite Damage to Buildings: Nature of Attacks and Preventive Construction Methods. American Journal of Engineering and Applied Sciences 4(2): 187200. DOI: 10.3844/ajeassp.2011.187.200

Jasmi, A. H., and Ahmad, A. H. 2011. Termite Incidence on an Araucaria Plantation Forest in Teluk Bahang, Penang. Insects 2(4): 469-474. DOI: 10.3390/insects2040469

Kang, H. Y., Matsushima, N., Sameshima, K., and Takamura, N. 1990. Termite Resistance Tests of Hardwoods of Kochi Growth. I. The Strong Termiticidal Activity of Kagonoki (Litsea coreana Leveille). Mokuzai Gakkaishi 36: 78-84.

Lee, S. H., H’ng, P. S., Cow, M. J., Sajap, A. S., Tey, B. T., Salmiah, U., and Sun, Y. L. 2011. Effectiveness of Pyroligneous Acid from Vapour Released in Charcoal Industry against 
Biological Attacks under Laboratory Condition. Journal of Applied Sciences 11(24): 38483853. DOI: $10.3923 /$ jas.2011.3848.3853

Liu, W. J., Li, W. W., Jiang, H., and Yu, H. Q. 2017. Fates of Chemical Elements in Biomass during Its Pyrolysis. Chemical Reviews 117(9): 6367-6398. DOI: 10.1021/acs.chemrev.6b00647

Montgomery, D. C. 1991. Design and Analysis of Experiments. Third Edition. John Wiley and Sons. New York.

Nandika, D., Rismayadi, Y., and Diba, F. 2003. Rayap: Biologi dan Pengendaliannya. Muhammadiyah University Press. Surakarta, Indonesia.

Oramahi, H. A. Diba, F., and Wahdina. 2011. Aktivitas Antijamur Asap Cair dari Serbuk Gergaji Kayu Akasia (Acacia mangium Willd) dan Kayu Laban (Vitex pubescens Vahl). Bionatura 13: 79-84.

Oramahi, H. A., and Yoshimura, T. 2013. Anti-Fungal and Antitermitic Activities of Wood Vinegar from Vitex Pubescens Vahl. Journal of Wood Science 59: 344-350. DOI: 10.1007/s10086-013-1340-8

Oramahi, H. A., Yoshimura, T., Diba, F., and Setyawati, D. 2018. Anti-Fungal and Antitermitic Activities of Wood Vinegar from Oil Palm Trunk. Journal of Wood Science 64(3): 311-317. DOI: $10.1007 / \mathrm{s} 10086-018-1703-2$

Oramahi, H. A., Diba, F., and Permana, R. D. 2020a. Optimasi Produksi Asap Cair dari Kayu Medang (Cinnamomum sp.) menggunakan Metode Permukaan Respon. EnviroScienteae. 16(1): 37-43. DOI: 10.20527/es.v16i1.8998

Oramahi, H., Yoshimura, T., Rusmiyanto, E., and Kustiati, K. 2020b. Anti-Fungal and Antitermitic Activities of Vinegars from Two Biomass Resources at Different Pyrolytic Temperatures. Journal of Applied Biological Sciences 14(1): 26-38.

Owoyemi, J. M., Kayode, J., and Olaniran, S. 2011. Evaluation of the Resistance of Gmelina arborea Wood Treated with Creosote Oil and Liquid Cashew Nut Shell to Subterranean Termites' Attack. Pro Ligno 7: 3-12.

Senter, S. D., Robertson, J. A., and Meredith, F. I. 1989. Phenolic Compound of the Mesocarp of Cresthaven Peaches during Storage and Ripening. Journal of Food Science 54: 1259-1268. DOI: $10.1111 /$ j.1365-2621.1989.tb05968.x

Shiny, K. S., and Remadevi, O. K. 2014. Evaluation of Termiticidal Activity of Coconut Shell Oil and Its Comparison to Commercial Wood Preservatives. European Journal of Wood and Wood Products. 72(1): 139-141. DOI: 10.1007/s00107-013-0755-7

Subekti, N., and Yoshimura, T. 2020. Activity of Bamboo Wulung's Smoke Gigantochloa atroviolace against Subterranean Termites And Fungi Attack. AGRIVITA, Journal of Agricultural Science 42(3): 543-549. DOI: 10.17503/agrivita.v42i3.2761

Temiz, A., Akbas, S., Panov, D., Terziev, N., Alma, M. H., Parlak, S., and Kose, G. 2013. Chemical Composition and Efficiency of Bio-Oil Obtained from Giant Cane (Arundo donax L.) as a Wood Preservative. Bioresources 8(2): 2084-2098.

Theapparat, Y., Chandumpai, A., Leelasuphakul, W., and Laemsak, N. 2015. Pyroligneous Acids from Carbonisation of Wood and Bamboo: Their Components and Anti-Fungal Activity. Journal of Tropical Forest Science 27(4): 517-526.

Wu, Q., Zhang, S., Hou, B., Zheng, H., Deng, W., Liu, D., and Tang, W. 2015. Study on the Preparation of Wood Vinegar from Biomass Residues by Carbonization Process. Bioresource Technology 179: 98-103. DOI: 10.1016/j.biortech.2014.12.026 